\title{
Beer and Allergens
}

\author{
Frank Vriesekoop (1)
}

Department of Food, Land and Agribusiness Management, Harper Adams University, Newport TF10 8NB, UK; fvriesekoop@harper-adams.ac.uk

\begin{abstract}
Food allergies are an important global health concern, with many countries following the World Health Organisation's guidelines with regards to due labelling of foods and, as such, providing forewarning about the presence of potential allergens to potential consumers. While for some produce, the link to specific allergens might be very clear to most consumers, this is not the case for all produce. People with specific food-related allergies usually know what to look out for, but occasionally, unexpected allergens are present in trusted produce. Beer is known to most to contain barley, which will contain gluten-like proteins that can cause allergic reactions in some people. Similarly, beer might contain sulphites and other potential allergens traditionally associated with beers. This review aims to examine a wide range of allergens that have entered the beer production process in recent years. As a result, examples of beers that contain one or more of the 14 EU-UK listed allergens are described, different allergen regulations in different countries are emphasised and their impact explained, and a number of case studies involving allergic reactions following exposure to and the ingestion of beer are highlighted.
\end{abstract}

Keywords: beer; allergens; workplace; gluten; cross-contamination; Cleaning in Place (CIP)

\section{Introduction}

There are multitudes of estimates that predict the prevalence of food-related allergies within the world's population. The estimates of the prevalence of food-related allergies range from $2 \%$ to close to $5 \%$ of the general population $[1,2]$, with self-diagnosed allergies being even more prevalent. Allergies can be defined as having an abnormal reaction when exposed to one or more compounds in a person's environment. This abnormal reaction is typically the result of an immune-system-related response that yields symptoms that can vary from mild discomfort to life-threatening situations! The most common routes that involve exposure to allergens are through the airways, gastrointestinal tract, and skin. This can lead to bronchoconstriction, abdominal pains, and skin rashes. Almost all food-related allergenic reactions yield abdominal-related symptoms, which are sometimes accompanied by skin rashes and hives [3].

The most complete listing of food allergens that require attention with regard to with regard to jurisdictional claims in published maps and institutional affiliations. the labelling of foods and beverages is the one enforced by the European Union (EU), which lists 14 allergens (Table 1). However, not all listed food categories or ingredients, such as sulphite and lactose, are not allergens in the traditional sense but still cause intolerance/irritative reactions [4], which cause discomfort.

There is a degree of ambiguity when it comes to the prevalence of food allergies. Many prevalence figures that are circulated are self-reported incidences, while medically evidenced incidences are often found in case studies with limited participants. Accurate figures regarding food allergy prevalence, as confirmed by food challenge studies, is resource-intensive, and the lack of global food challenge studies is the leading cause of the limited availability of quality data [5]. However, the scarcity of quality data is further exacerbated by the inconsistent definitions and methodologies employed. Most of the available data are based on self-reporting, which generally overestimates food allergy prevalence by a factor of three to four [5]. However, in order to provide an overview of the prevalence of 
the main food allergens listed in Table 1, we report the self-reported prevalences according to the 2013 EFSA report [6]. Celery and milk are the most commonly self-reported allergens. Gluten is the most common beer-associated allergen [7]. Gluten-containing cereals and the produce derived from them have a self-reported allergen prevalence of 1.13\% (Table 1), which is closely aligned to the incidence of coeliac disease worldwide [8].

Table 1. Common food allergens, listed by prevalence.

\begin{tabular}{|c|c|c|}
\hline Allergen & Common Descriptor & Prevalence in EU Population (\%) [6] \\
\hline Celery & Includes celery stalks, leaves, seeds and the root (celeriac) & 5.50 \\
\hline Milk & $\begin{array}{l}\text { Secretion from mammary glands intended to be the } \\
\text { nutritional input of mammalian neonates }\end{array}$ & 3.84 \\
\hline Mustard & $\begin{array}{c}\text { Member of the brassica family. Limited cross-reactivity from } \\
\text { other brassica }\end{array}$ & 3.00 \\
\hline Eggs & $\begin{array}{c}\text { Typically refers to hen eggs but does not exclude eggs from } \\
\text { other birds }\end{array}$ & 2.85 \\
\hline Peanuts & $\begin{array}{l}\text { Also known as a groundnut. The peanut is not a nut; } \\
\text { instead, it is a legume }\end{array}$ & 2.59 \\
\hline Fish & $\begin{array}{l}\text { Typically, a limbless cold-blooded } \\
\text { vertebrate animal with gills and fins, living in water }\end{array}$ & 2.53 \\
\hline Crustaceans & $\begin{array}{l}\text { Includes crabs, lobster, shrimp, } \\
\text { prawns, and scampi }\end{array}$ & 1.80 \\
\hline Tree nuts & $\begin{array}{c}\text { Includes a wide range of nuts. Fruit composed of a hard } \\
\text { shell and an indehiscent seed }\end{array}$ & 1.45 \\
\hline Cereals/Gluten & $\begin{array}{l}\text { Cereals containing gluten or gluten-like proteins, such as } \\
\text { wheat, rye, barley, and oats }\end{array}$ & 1.13 \\
\hline Molluscs & $\begin{array}{c}\text { Typically includes mussels, oysters, abalone, squid, } \\
\text { and snails }\end{array}$ & 1.00 \\
\hline Sesame seeds & $\begin{array}{c}\text { Sesame is a flowering plant whose seeds yields very large } \\
\text { amounts of oil }\end{array}$ & 0.70 \\
\hline Soy & $\begin{array}{l}\text { A high oil- and protein-yielding legume. Can show } \\
\text { cross-reactive to other legumes }\end{array}$ & 0.53 \\
\hline Lupin & $\begin{array}{c}\text { A legume belonging to the same family as peanuts. Hence, } \\
\text { cross-reactivity to peanuts is common }\end{array}$ & $\mathrm{NR}^{1}$ \\
\hline Sulphites & $\begin{array}{l}\text { Chemical preservative and antioxidant, typically reported } \\
\qquad \text { as } \mathrm{SO}_{2}\end{array}$ & $\mathrm{NA}^{2}$ \\
\hline
\end{tabular}

${ }^{1}$ Non-recorded. no population-based studies on the prevalence of lupin allergy worldwide. ${ }^{2}$ Not applicable. Sulphites are an irritant and are not true allergens.

While the EU has the most extensive list of allergens with regards to labelling requirements, other countries and regions have included less or, occasionally, other allergens that require compulsory inclusion in food and beverage labels (Table 2). For instance, sesame seeds, lupin, mustard and celery are included in the EU's (and the UK's and Turkey's) list of reportable allergens, but they are not on most other countries' lists. Sesame seeds and products derived from them are reportable allergens in Australia, New Zealand, Canada, and Taiwan, and from January 2023, sesame will also be included in the allergen list in the USA (Table 2).

In some countries, the term "shellfish" or "seafood" is included as a reportable allergen. In some instances, the term "seafood" means both crustaceans and molluscs (e.g., South Africa); however, in the USA [9], the term shellfish is preceded by "crustacean" to read "crustacean shellfish", with no mention of molluscs. Along similar lines, molluscs are not mentioned in allergen-related food regulations in China, Argentina, Chile, and Mexico (Table 2).

A different approach is taken in Japan, where compulsory labelling is required for six allergens (dairy products, egg, crustaceans (shrimps and crab only), wheat, buckwheat and peanuts (Table 2)), while for fish (salmon and mackerel only), molluscs (abalone and squid only), tree nuts, soy, and sesame, there is only a recommendation for the labelling of those allergens [10]. 
Table 2. Country/region-specific allergens that require compulsory inclusion on food and beverage labels.

\begin{tabular}{|c|c|c|c|c|c|c|c|c|c|c|c|c|c|c|c|c|c|}
\hline Country/Region & 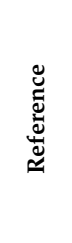 & 妾 & 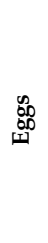 & 蛋 & 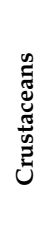 & $\begin{array}{l}0 \\
0 \\
D \\
\overline{0} \\
\sum\end{array}$ & 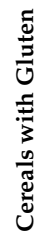 & $\begin{array}{l}\text { Еँ } \\
\text { एँ }\end{array}$ & 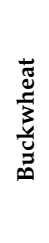 & 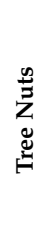 & 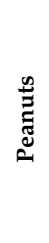 & $\vec{b}$ & 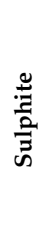 & 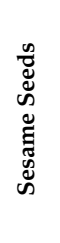 & 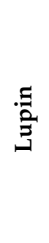 & 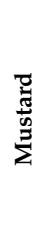 & $\frac{\overrightarrow{0}}{\tilde{e}}$ \\
\hline $\mathrm{EU}$ & [11] & $\checkmark$ & $\checkmark$ & $\checkmark$ & $\checkmark$ & 2 & $\checkmark$ & $\otimes$ & $\varnothing$ & $\checkmark$ & $\checkmark$ & $\checkmark$ & $\checkmark$ & $\checkmark$ & $\checkmark$ & $\checkmark$ & $\checkmark$ \\
\hline UK & [12] & $\checkmark$ & $\checkmark$ & $\checkmark$ & $\checkmark$ & $\checkmark$ & $\checkmark$ & $\otimes$ & $\varnothing$ & $\checkmark$ & $\checkmark$ & $\checkmark$ & $\checkmark$ & $\checkmark$ & $\checkmark$ & $\checkmark$ & $\checkmark$ \\
\hline Turkey & [13] & $\checkmark$ & $\checkmark$ & $\checkmark$ & $\checkmark$ & $\checkmark$ & $\checkmark$ & $\otimes$ & $\varnothing$ & $\checkmark$ & $\checkmark$ & $\checkmark$ & $\checkmark$ & $\checkmark$ & $\checkmark$ & $\checkmark$ & $\checkmark$ \\
\hline Australia & {$[14]$} & $\checkmark$ & $\checkmark$ & $\checkmark$ & $\checkmark$ & $\checkmark$ & $\checkmark$ & $\otimes$ & $\varnothing$ & $\checkmark$ & $\checkmark$ & $\checkmark$ & $\checkmark$ & $\checkmark$ & $\checkmark$ & $\varnothing$ & $\varnothing$ \\
\hline New Zealand & {$[14]$} & $\checkmark$ & $\checkmark$ & $\checkmark$ & $\checkmark$ & $\checkmark$ & $\checkmark$ & $\otimes$ & $\varnothing$ & $\checkmark$ & $\checkmark$ & $\checkmark$ & $\checkmark$ & $\checkmark$ & $\checkmark$ & $\varnothing$ & $\varnothing$ \\
\hline USA & [9] & $\checkmark$ & $\checkmark$ & $\checkmark$ & $\checkmark$ & $\varnothing$ & $\varnothing$ & $\checkmark$ & $\varnothing$ & $\checkmark$ & $\checkmark$ & $\checkmark$ & $\checkmark$ & $\boldsymbol{J}^{1}$ & $\varnothing$ & $\varnothing$ & $\varnothing$ \\
\hline Canada & [15] & $\checkmark$ & $\checkmark$ & $\checkmark$ & $\checkmark$ & $\checkmark$ & $\checkmark$ & $\checkmark$ & $\varnothing$ & $\checkmark$ & $\checkmark$ & $\checkmark$ & $\checkmark$ & $\checkmark$ & $\varnothing$ & $\checkmark$ & $\varnothing$ \\
\hline Taiwan & {$[16]$} & $\checkmark$ & $\checkmark$ & $\checkmark$ & $\checkmark$ & $\varnothing$ & $\checkmark$ & $\otimes$ & $\varnothing$ & $\checkmark$ & $\checkmark$ & $\checkmark$ & $\checkmark$ & $\checkmark$ & $\varnothing$ & $\varnothing$ & $\varnothing$ \\
\hline FAO-WHO & [17] & $\checkmark$ & $\checkmark$ & $\checkmark$ & $\checkmark$ & $\varnothing$ & $\checkmark$ & $\otimes$ & $\varnothing$ & $\checkmark$ & $\checkmark$ & $\checkmark$ & $\checkmark$ & $\varnothing$ & $\varnothing$ & $\varnothing$ & $\varnothing$ \\
\hline China & {$[18]$} & $\checkmark$ & $\checkmark$ & $\checkmark$ & $\checkmark$ & $\varnothing$ & $\checkmark$ & $\otimes$ & $\varnothing$ & $\checkmark$ & $\checkmark$ & $\checkmark$ & $\checkmark$ & $\varnothing$ & $\varnothing$ & $\varnothing$ & $\varnothing$ \\
\hline Mexico & [19] & $\checkmark$ & $\checkmark$ & $\checkmark$ & $\checkmark$ & $\varnothing$ & $\checkmark$ & $\otimes$ & $\varnothing$ & $\checkmark$ & $\checkmark$ & $\checkmark$ & $\checkmark$ & $\varnothing$ & $\varnothing$ & $\varnothing$ & $\varnothing$ \\
\hline Russia & [20] & $\checkmark$ & $\checkmark$ & $\checkmark$ & $\checkmark$ & $\varnothing$ & $\checkmark$ & $\otimes$ & $\varnothing$ & $\checkmark$ & $\checkmark$ & $\checkmark$ & $\checkmark$ & $\varnothing$ & $\varnothing$ & $\varnothing$ & $\varnothing$ \\
\hline Argentina & [21] & $\checkmark$ & $\checkmark$ & $\checkmark$ & $\checkmark$ & $\varnothing$ & $\checkmark$ & $\otimes$ & $\varnothing$ & $\checkmark$ & $\checkmark$ & $\checkmark$ & $\checkmark$ & $\varnothing$ & $\varnothing$ & $\varnothing$ & $\varnothing$ \\
\hline Brazil & [22] & $\checkmark$ & $\checkmark$ & $\checkmark$ & $\checkmark$ & $\varnothing$ & $\checkmark$ & $\otimes$ & $\varnothing$ & $\checkmark$ & $\checkmark$ & $\checkmark$ & $\checkmark$ & $\varnothing$ & $\varnothing$ & $\varnothing$ & $\varnothing$ \\
\hline Chile & [23] & $\checkmark$ & $\checkmark$ & $\checkmark$ & $\checkmark$ & $\varnothing$ & $\checkmark$ & $\otimes$ & $\varnothing$ & $\checkmark$ & $\checkmark$ & $\checkmark$ & $\checkmark$ & $\varnothing$ & $\varnothing$ & $\varnothing$ & $\varnothing$ \\
\hline India & [24] & $\checkmark$ & $\checkmark$ & $\checkmark$ & $\checkmark$ & $\varnothing$ & $\checkmark$ & $\otimes$ & $\varnothing$ & $\checkmark$ & $\checkmark$ & $\checkmark$ & $\checkmark$ & $\varnothing$ & $\varnothing$ & $\varnothing$ & $\varnothing$ \\
\hline Vietnam & {$[24]$} & $\checkmark$ & $\checkmark$ & $\checkmark$ & $\checkmark$ & $\varnothing$ & $\checkmark$ & $\otimes$ & $\varnothing$ & $\checkmark$ & $\checkmark$ & $\checkmark$ & $\checkmark$ & $\varnothing$ & $\varnothing$ & $\varnothing$ & $\varnothing$ \\
\hline Thailand & [24] & $\checkmark$ & $\checkmark$ & $\checkmark$ & $\checkmark$ & $\varnothing$ & $\checkmark$ & $\otimes$ & $\varnothing$ & $\checkmark$ & $\checkmark$ & $\checkmark$ & $\checkmark$ & $\varnothing$ & $\varnothing$ & $\varnothing$ & $\varnothing$ \\
\hline Japan & [10] & $\checkmark$ & $\checkmark$ & V & $\checkmark$ & V & $\varnothing$ & $\checkmark$ & $\checkmark$ & $\nabla$ & $\checkmark$ & $\nabla$ & $\varnothing$ & $\nabla$ & $\varnothing$ & $\varnothing$ & $\varnothing$ \\
\hline Korea & [24] & $\checkmark$ & $\checkmark$ & $\checkmark$ & $\checkmark$ & $\checkmark$ & $\varnothing$ & $\checkmark$ & $\checkmark$ & $\checkmark$ & $\checkmark$ & $\checkmark$ & $\checkmark$ & $\varnothing$ & $\varnothing$ & $\varnothing$ & $\varnothing$ \\
\hline South Africa & [25] & $\checkmark$ & $\checkmark$ & $\checkmark$ & $\checkmark$ & $\checkmark$ & $\checkmark$ & $\otimes$ & $\varnothing$ & $\checkmark$ & $\checkmark$ & $\checkmark$ & $\varnothing$ & $\varnothing$ & $\varnothing$ & $\varnothing$ & $\varnothing$ \\
\hline
\end{tabular}

$\checkmark$ Mandatory labelling. $\square$ Recommended labelling only. $\otimes$ Not explicitly in a category heading, but included within the "cereal with gluten" category. $\varnothing$ No explicit labelling requirement. ${ }^{1}$ Sesame becomes a mandatory reportable allergen from January 2023 in the USA.

Among the 14 allergens required to be listed in the EU, there are three that are commonly encountered in many mainstream beers and two that can be found in more traditional specialty beers, while all of those 14 allergens can be encountered in some more contemporary craft beers (Table 2).

\section{Allergenic Reactions and Beer}

Beer has been an intrinsic part of human culture for millennia [26], and while beer is produced and consumed all over the world, beer-related allergies are rare. The rarity of beer-related allergies does not mean that these allergies can be dismissed. A number of allergic reactions related to beer have been reported and range from full-blown anaphylaxis to urticaria (hives) and diffuse erythema (localised reddening (inflammation of blood capillaries) of the skin). Diffuse erythema typically presents itself as facial flushing and is usually associated with the consumption of ethanol $[27,28]$ and is not unique to the consumption of beer. Contact urticaria (with and without obvious angioedema) has been reported [29-32]. In most of these cases, the individuals were found to be sensitive to the serum IgE from malt. Beer is an uncommon cause of anaphylaxis [33]; however, cases of anaphylaxis following the consumption of beer have been reported [33-42].

\subsection{Case Studies-Beer Causing Allergic Reactions}

In one case study [33], a 32-year-old male had a 15-year history of allergic reactions following the consumption of beer. Upon a clinical investigation, it was found that the patient showed sensitivity to beers and cereals in a series of prick tests but no sensitivity to either yeast or hops by themselves. A similar case was reported where a 21-year-old 
male developed anaphylaxis following the consumption of beer, while other alcoholic beverages did not present allergic responses [38]. Upon a clinical investigation, it was found that the patient showed sensitivity to a range of beers but not to yeast. In yet another case, Figueredo et al. [34] highlighted a 21-year-old female who developed anaphylaxis immediately following the consumption of beer. This patient had a history of allergic reactions to mustard and rosaceae fruits; the consumption of bread or other baked products did not cause any allergic reactions. In a series of prick tests, she showed sensitivities to beer, malt, barley, corn, wheat, rye, rice, oats, rosaceae fruit and tree nuts but tested negative to hops and brewers' yeast [34]. Fernández-Anaya et al. [35] presented three cases of beer anaphylaxis (a 20-year-old male, a 22-year-old female and a 24-year-old female). All patients presented with anaphylaxis following the consumption of beer but tolerated the consumption of wheat bread and other alcoholic beverages. All three patients reacted positively to barley and beer in a series of prick tests [35]. Conversely, Herzinger et al. [39] reported a case of a 59-year-old male who was a regular beer drinker who developed anaphylaxis following the consumption of wheat beer. The person had no history of allergic reactions; he drank wine and lager beers and ate bread. In a series of prick tests, the patient showed sensitivity to wheat beers, wheat allergens and barley allergens but not to hops or brewers' yeast. While the patient tested positive for wheat and barley allergens, these were of no clinical relevance since beers made from barley only were tolerated without problems [39]. Brussino et al. [42] reported a special case of a 29-year-old female who regularly consumed beer without any allergic reaction; however, this person did develop anaphylaxis within minutes of consuming a beer. The person suffered from hayfever in childhood but had no history of food allergies. Upon a clinical investigation, it was found that the patient showed sensitivity to one beer only out of a series of beers. A more in-depth investigation showed that the patient showed sensitivity to coriander-flavoured beer, coriander extract, tree nuts and grass pollen, while negative tests were recorded for all other beers, hops and brewers' yeast [42]. Quercia et al. [40] reported a 45-year-old male with repeated episodes of diffuse urticaria, angioedema of the face, swelling of the oral mucosa, and dyspnoea, always shortly after drinking beer. This patient tested positive following prick tests to barley, corn, and 30 out of 35 beers but tested negative to brewers' yeast. Among the beers for which the patient tested negative were two all-malt beers, a beer that contained wheat as an ingredient, and two beers with non-grain sugar adjuncts. The consumption of any of those five beers caused no allergic reaction following their controlled consumption [40]. Furthermore, Asero et al. [37] also reported a case of a 19-year-old male with varied urticaria and angioedema following the consumption of beer. The patient did not react equally to all brands of beer. A prick test with one beer brand did not yield a positive response; however, the patient showed a significant response to a range of fruits and an extreme response to peach lipid transport protein [37]. In a multicase report by Song et al. [41], 15 out of 20 beer-related anaphylaxes could be identified to specific beer allergens through prick tests. Among the beer-specific allergens were barley and barley malt, but there were also nine positive prick tests towards sorghum or millet, with five positive prick tests towards yeast and five positive prick tests towards hops. In another multicase report by Garcia-Casado et al. [43], four adults tested positive to prick tests with a crude protein extract from beer. All patients also tested positive to a purified barley lipid transport protein, while only two out of four patients tested positive to a purified $Z_{4}$ protein preparation [43]. Inoue et al. [44] also reported $\mathrm{Z}_{4}$ as an active barley-related antigen to cause hypersensitivity to beer in a 26-year-old female following the consumption of beer, while the consumption of bread and other baked products did not elicit any symptoms. These results indicate that the individual proteins linked to an allergic response related to beer are varied but with the same overall outcome. The series of case studies summarised above show that wheat and barley allergen are common causes of beer-related anaphylaxis but that an allergic reaction towards one does not necessarily include the other. Additionally, hops and yeast and even coriander have been identified as the causative agents in beer-related anaphylaxes. 


\subsection{Beer-Related Allergic Reactions in the Workplace}

People working in the brewing and allied industries, with sensitivities to various beerassociated food allergies, may suffer from a much wider range of symptoms because their route of exposure to potential allergens is much more diverse, including direct exposure to their nasal cavity, eyes, and skin. Asthma and related allergic reactions are not uncommon among grain workers, where, in most instances, the asthmatic responses were related to dust particles, causing the production of excessive phlegm without positive prick tests to typical beer-related antigens $[45,46]$. Workers in the malting industry have shown sensitivities to barley and malt but usually test negative to prick tests involving a range of cereals; however, they might test positive to malt [47]. Open floor maltings and Saladin box maltings cause more dust-related issues compared to enclosed drum maltings [46]; however, drum maltings are being phased out in favour of automated Saladin box maltings and tower maltings, where human exposure to the whole process is extremely limited. Workers in the hops industry have been reported to suffer from hops-related asthma and urticaria $[48,49]$, with a much higher incidence of respiratory symptoms among hops workers compared to a control group of other crop workers [49]. The incidence of positive prick tests in response to hops was higher when using an extract from leaves compared to the extract from hop cones [48], which goes some way to explaining the incidence of occupational allergies related to hops by brewery workers [50]. However, brewery workers have also been shown to have sensitivities to various ingredients, including the extracts of hops, barley and brewers' yeast. Godnic-Cvar et al. [51] reported that among a large group $(n=97)$ of brewery workers, the principal cause of positive prick test results was from sensitivities to dust mites (22\%), with $15 \%$ to barley and hops each and $14 \%$ with a positive test for brewers' yeast.

A case of contact urticaria was reported in a 20-year-old female working in a bar [29], where the contact urticaria was focused on the hands and forearms following direct contact with beer while working in a bar. However, the patient could drink beer without any adverse reactions [29].

\section{Allergens Found in Beer}

\subsection{Gluten (Wheat and Other Cereals with Gluten-Like Proteins) as Allergens in Beer}

The most common and most difficult to avoid allergen that is associated with beer is gluten, which is contained within all common beer-associated cereals. Adverse reactions to gluten can be a general intolerance to gluten or, more specifically, coeliac disease $[8,52,53]$. Coeliac disease is an autoimmune disorder in which gluten triggers an inflammation of the intestinal tract [53], whereas intolerance to gluten is often described as an allergic reaction to gluten, best referred to as gluten-related disorder [54]. The symptoms and their descriptions vary widely and include abdominal bloating, chronic diarrhoea, constipation, nausea, and vomiting [52-54]. In general, gluten-related disorders can be summarised as "a chronic small intestinal immune-mediated enteropathy precipitated by exposure to dietary gluten in genetically predisposed individuals" [54]. Gluten represents a significant fraction of the storage proteins in grains. Although gluten is the term most commonly associated with wheat, proteins with similar allergenic reactivity have different nomenclatures in other grains [55]. Wheat is by far the most gluten-abundant grain and is at times the "centre-piece" grain when it comes to allergen labelling. For instance, in the USA, Japan and Korea, wheat is the only grain that requires allergen-related labelling (Table 2); in other countries, wheat is included under a more generic description such as "cereals containing gluten", often with an additional explanation such as "namely, wheat, rye, barley, oats and their hybridised strains and products thereof". In most countries, the requirement for gluten labelling for food (including beers) is set at any level below $20 \mathrm{ppm}$, which means that produce with a gluten level below $20 \mathrm{ppm}$ do not require gluten-related allergen labelling. However, in Australia and New Zealand, labelling requirements are more fluid. In Australia and New Zealand, gluten labelling is required if gluten is detectable with the most common gluten detection method [56]. This means that with more refined testing 
methods being developed and approved for use for gluten analysis, the threshold for compulsory gluten labelling will decrease over time.

Wheat gluten is a mixture of many different proteins that can be categorised as glutenins and gliadins. The gliadins are predominantly prolamins and make up roughly $70 \%$ of the gluten. Similar prolamine fractions can also be found in barley (hordiens) and rye (secalin), all of which raise allergen concerns [57,58]. While the gliadins from wheat, barley and rye are not identical, they all share a similar amino acid sequence of 33 amino acids referred to as the "33-mer peptide" [59], which is the immunological epitope responsible for coeliac disease. While wheat, barley and rye contain proteins that can trigger an allergic response linked to gluten [59], oats themselves do not contain any such proteins that contain known coeliac [60]. However, since the farming of oats often involves crop rotations where oats are planted following a wheat crop, it is near impossible to exclude wheat from an oats crop, and oats, as found in the retail chain, are generally not guaranteed free of gluten when processed in a conventional production line because of unintentional cross-contamination with wheat, rye or barley [60].

Occupation-related gluten allergies are reported among bakers [61]; however, similar reports related to people working in the malting or brewing industry are rare [51]. It is likely that individuals in the brewing industry that have gluten-related allergies themselves are very interested and instrumental in the development and production of gluten-free beers [52].

The general popularity of beer has created a niche for specialty beers that can be drunk by those consumers who have a gluten allergy or intolerance. Broadly speaking, there are two approaches to making gluten-free beer. The most established approach to overcome gluten intolerance problems has been to produce beers solely from cereals and pseudocereals that do not contain gluten, such as rice, sorghum, millet, or buckwheat $[62,63]$. Some of these gluten-free beers are made with a single non-gluten grain variety, but most are being produced with a range of non-gluten containing cereals and pseudo-cereals. Associated with the use of cereals and pseudo-cereals that are naturally devoid of gluten, it would also be possible to produce beers with barley varieties that have been bred with ultra-low gliadin content [64,65]. Furthermore, it should be noted that while various pseudo cereals contain no gluten, buckwheat, sorghum and millet are capable of causing anaphylaxis in sensitive individuals $[41,66]$. As a result, occasionally, such as in Japan and Korea, buckwheat is a reportable allergen (Table 2), which implies that a beer with an absence of gluten does not mean a beer devoid of allergen risks.

Secondly, a more technical approach has been used as well to produce beers without detectable levels of gluten; this approach utilises natural processes that reduce the detectable levels of gluten. There are three sub-approaches to the production of barleycontaining beers with gluten levels below the typical $20 \mathrm{ppm}$ labelling threshold. The most simplistic method is to use a dilution method, where the presence of barley is minimised through the inclusion of mashable adjunct grains that are devoid of gluten, such as corn or rice, or through the addition of refined kettle adjuncts (sucrose, glucose syrups, and maltodextrins) [67]. In this method, the level of gluten is reduced through a reduction in the relative quantity of barley malt included in the production of beer. Another technical approach is the extension of the various production steps in the production of "glutenreduced" beer $[68,69]$. Watson et al. [68] showed that stepped-temperature mashing in combination with filtration (lautering) was capable of causing a $50 \%$ reduction in detectable gluten, while wort boils, fermentation and subsequent maturation could achieve an allbarley malt beer with a detectable gluten level below 20 ppm. Extending the mashing process would result in a greater extract yield but also in even greater degradation of the hordeins by endogenous malt enzymes $[57,58,69]$. A third approach to reducing the detectable levels of gluten in beer is to employ a de-glutinisation step by using an exogenous propyl endopeptidase that is highly active toward coeliac-active substances [70-72]. The exogenous propyl endopeptidase that is extensively being used in the production of barley-malt-derived gluten-free beer is produced by a genetically modified strain of 
Aspergillus niger, which contains multiple copies of its own propyl endopeptidase gene [26]. The enzyme preparation is marketed as "Brewers Clarex" and has been used historically to reduce the protein loading in beers in order to minimise haze formation in beers [70] by hydrolysing haze-sensitive proteins. While the propyl endopeptidase could be added to the mashing stage in the brewing sequence, the subsequent wort boil would eliminate all peptidase activity. Therefore, propyl endopeptidase is most commonly added post-wort boil, at the start of the fermentation. The effectiveness of this enzymatic approach is probably underpinned by the fact that the typical brewing process (mainly during mashing) already causes a $99 \%$ reduction in gluten levels in all-malt beer formulations $[57,58]$.

The wellbeing of coeliacs when consuming these gluten-reduced beers remains a topic of debate $[70,73,74]$. In the EU and the UK, gluten-reduced beers can be described as gluten-free. However, in the US, Canada, Australia and New Zealand, they cannot be described as gluten-free. Instead, they are typically described as "gluten-removed" or "gluten-reduced" beers and can be labelled "processed to remove gluten". The main argument is that even following the extended mashing process or the addition of endogenous propyl endopeptidase, the hydrolysed gliadins still contain coeliac-related epitopes that are capable of causing an immunological response in coeliac patients $[73,74]$.

\subsection{Exemptions}

In various countries, there are exemptions and permanent exclusions with regards to labelling requirements for the use of food ingredients derived from cereals containing gluten. In the EU, these cover wheat-based glucose syrups, including dextrose, wheat-based maltodextrins, glucose syrups based on barley, cereals used for making distillates or ethyl alcohol of agricultural origin for spirit drinks and other alcoholic beverages (EU directive $2000 / 13 / E C, 2000$ ). In all these instances, it has been recognised that in the processes involved in creating the products/ingredients from the raw materials, the coeliac-related epitopes are either destroyed or removed from the final product.

\subsection{Fish as Allergens in Beer}

The notion of whole fish as an ingredient in the production of beer might raise an eyebrow; however, the inclusion of any material originating from fish has to be labelled as an allergen. The only fish-related product that is not uncommon in the production of beer is isinglass. Isinglass (produced from fish bladders) can be added to freshly fermented beer toward the end of the fermentation in order to aid in the removal of yeast $[26,75,76]$, or, in the case of cask ales, to facilitate the elimination of yeast and proteins by precipitation from the potable portion of cask-conditioned ales [77]. Apart from its use in beer, isinglass is also used in wine production to enhance colloidal stability [78] and colour stability [79].

Isinglass is a purified form of collagen derived from fish swim bladders. Not all fish possess swim bladders, and the most effective isinglass for fining purposes is produced from (sub)tropical fish. How dense or fluffy the precipitate depends on the fish species the isinglass is produced from [77]. Threadfin swimbladders yield isinglass that produces a very dense settlement, whereas catfish-derived isinglass produces a more flocculent settlement [77]. In order to achieve a fining quality for a specific beer style, two or more kinds of isinglass might be blended.

Collagen is a tightly intertwined triple-helical protein structure, high in glycine and proline residues, with the glycine residues typically facilitating the interhelical connections [80]. In the production of isinglass, the swimbladders are "cut" by acid solubilisation ( $\mathrm{pH} 2.5-3.0$ at $10-15^{\circ} \mathrm{C}$ ) of the collagen helix, which partially unravels the helical structure [77]. There have been no substantiated reports of allergic reactions linked to isinglass in alcoholic beverages [26]. Nonetheless, in 2003, the EU adopted Directive 2003/89/EC1 with regard to the compulsory labelling of a number of ingredients present in foodstuffs that are known to induce allergic reactions or intolerances in sensitive individuals. This list includes fish and fish-derived products. The directive states that whenever the listed ingredients/substances or their derivatives are used in the production of foodstuffs, they 
must be labelled without exception. Directive 2003/89/EC1 was successfully challenged by the Brewers of Europe and the Brewing, Food and Beverage Industry Suppliers Association (BFBi), citing various specific clinical trials on fish collagen that showed that none of the fish-challenged allergic individuals had a positive reaction to it [81,82]. Upon investigation by an EU investigative panel, it was determined that it was not likely that isinglass, when used as a clarifying agent in beer, would induce a severe allergic reaction in susceptible individuals under the conditions of production and its use specified in the challenge. As a consequence of this opinion, the EU established, with Commission Directive 2007/68/EC, a permanent exception for the labelling of fish gelatine or isinglass when used as a fining agent in beer and wine [83].

Nonetheless, replacements for isinglass in the production of beer is still being pursued. Apart from avoiding fish-derived ingredients or processing aids, a parallel driver has been a demand for beers that fit a vegan lifestyle. In order to address the notion of avoiding piscine isinglass in the production of beer, isinglass equivalences have been developed using avian and bovine collagen, with good results $[77,84]$. This, however, does not address the vegan lifestyle conundrum. Both plant-based [84] and mineral-based alternatives have also been investigated, with a proprietary silica/polysaccharide-blended formulation being widely used in the industry.

\subsection{Molluscs as Allergens in Beer}

Molluscs are a clade of invertebrates with soft bodies that typically contain a "head" and a "foot" region and include bivalves, gastropods, and cephalopods, which represent most of the molluscs consumed as human food. The bodies of bivalves and gastropods are often covered by a hard exoskeleton in the form of a shell, while in cephalopods, the shell is typically internalised [85].

The allergic response related to molluscs is predominantly due to tropomyosin. Tropomyosins are myofibrillar proteins involved in muscle contraction, found in both molluscs and crustaceans [86,87].

There is ample anecdotal information available that describes the application of oysters in stouts. It appears that great variations occur in the application of oysters in the production of stouts. This varies from the addition of oyster shells to the mash tun, the addition of oyster flesh or extract to the kettle, the addition of oyster flesh or extract to the fermenter, the addition of oysters to the finished beer, or, sometimes, no addition of oysters at all. The application of oysters to the beer production process is said to improve the head retention and flavour of stout [88]. The addition of oyster shells at the end of the mash is said to extract calcium carbonate from the shells, which helps reduce the tannic astringency that can result from the roasted grains used in stouts [26], which will yield a water makeup similar to the hard water used in typical stout brewing areas. To date, there have been no reported cases of mollusc-related allergic reactions following the consumption of oyster stout. Other than the well-establish quintessential oyster stouts, abalone, cockles, mussels and squid ink have also been used in the production of speciality beers. In Belgium, an imperial mussel stout ("Mussels in Brussels") has been produced with fresh mussels (both meat and shells) for minerality and full-bodiedness (Siphon Brewery, Belgium) [C01]. An Australian brewery has produced a series of abalone beers (Red Duck Brewery, Australia) [C02], while a British brewery produced a cockle stout, with the cockles being added towards the end of the wort boil [C03]. Furthermore, a number of dark sour beers (gose) and IPAs have been produced using squid ink as an ingredient (e.g., "Squid Ink XXPA", Shelter Brewery [C04]; "Squid Ink Gose", Time \& Tide Brewery [C05]; "Black Magic Salt \& Pepper Squid Ink Gose", Dainton Brewery [C06]).

\subsection{Crustaceans as Allergens in Beer}

The term crustaceans apply to a large and diverse group of both fresh water and saltwater arthropods that includes crabs, lobster, shrimps, prawns, and barnacles [89]. The typical crustacean body is covered by a hard exoskeleton, which must be shed for 
the animal to grow. Crustacean-allergic individuals can experience moderate to strong adverse immunological reactions, including anaphylaxis [90]. Similar to molluscs, the major crustacean-related allergen is tropomyosin, which has a highly conserved sequence among all crustaceans [91]. Hence, many individuals may have concurrent allergies to a broad range of crustaceans [87].

The notion of crustaceans used in the production of beer is rare. However, on those very rare occasions, lobsters have been added to the wort boil. This usually involves the addition of live lobsters to boiling wort for just long enough to cook the lobster meat. The lobsters can then be retrieved from the boiling wort and consumed for their meat. In the production of "Saison dell'Aragosta" [C07], Oxbow Brewing in Maine returned the lobster shells to the boiling wort to impart a more in-depth flavour profile [92].

\subsection{Milk as an Allergen in Beer}

Milk and milk-derived products, including lactose, typically require compulsory labelling. The regulatory terminology varies from country to country. For instance, in the UK and the EU, the regulatory wording is "milk and products thereof, including lactose", while in Chile, China and Russia, it states "milk and dairy products (including lactose)". In Argentina, the regulatory wording states, "milks obtained from mammals of all species admitted for consumption", which includes all milk-derived products. In Australia and New Zealand, the regulatory wording states "all dairy products" and "any product containing the word milk ... including goat's milk, ewe's and sheep's milk and milk from other animals", which includes lactose. In the USA, it simply states "milk ... and ingredients that contain proteins derived from milk". It does not explicitly mention lactose because lactose is not considered an actual allergen in the USA. On the other hand, in South Africa, only cow's milk and goat's milk are explicitly mentioned, while in Japan, the regulatory wording simply mentions "dairy products"; in Korea, it mentions "milk" only.

Milk-related allergies are sometimes confused with milk intolerance (the latter being more common), which can produce symptoms that are similar to those of milk allergy but not to the same extent [93]. In contrast to milk allergy, milk intolerance is a nonimmunological response, causing disorders in digestion, absorption, or metabolism. A common example is the malabsorption of lactose, which is classified as a metabolic disease. The actual milk allergens are represented by a large number $(<25)$ of milk-related proteins. Of those, five are prominent casein proteins, and four are prominent whey proteins [93]. Of those, Bos d 4 through to Bos d 6 are major whey proteins, and Bos d 9 through to Bos $\mathrm{d} 12$ are major casein-related proteins [93].

With regards to the use of milk in the production of beer, an early patent was granted for the production of a milk beer containing malt, whey, and hops [94], but no direct information can be found regarding the application of intact milk in the production of either milk beer or milk stout. A number of attempts have been made to produce beers or beer-like beverages with whey [95]. In some, the whey sugars were targeted as the sources of ethanol by employing lactose-fermenting yeast [96], while in others, the presence of lactose caused product spoilage [97]. Hesse [98] described the use of whey in the production of beer and beer-like beverages. Hesse went on to categorise these beverages as, for instance, malt-whey beer or whey-malt beer, depending on their approximate whey content. A malt-whey beer would contain $30 \%(v / v)$ whey, and a whey-malt would contain at least $50 \%(v / v)$ whey [98]. Over the years, the addition of whey during beer production has yielded stouts where the typical astringency is masked by the sweetness of the nonfermentable lactose contained in the whey [99]. The designation "milk stout" became prohibited in the United Kingdom in 1946 after it was determined by the courts that it could lead to misleading consumers in thinking that beer labelled as milk stouts contained milk, while, in fact, it was only lactose that was added as an ingredient to the beers labelled as "milk stout" [100]. Since that time, the labelling terminology for stouts containing lactose has been adjusted to "sweet stout". The use of lactose in the production of "milk stouts" or "sweet stouts" is still commonplace today [99]. The use of lactose as 
an active ingredient in beers has undergone a resurgence in beers such as "ice cream" and "milkshake" IPAs, such as the Northern Monk "Neapolitan Ice Cream IPA" [C08] and the Stone and Wood "Mango Milkshake IPA" [C09]. These IPAs are subcategories within contemporary New England IPAs (NEIPAs), which are characterised by their distinct haziness, strong aromatic hops and noticeable sweetness. In comparison, sweet stouts contain between $1.5 \%$ to $2.5 \%$ lactose, while the ice cream and milkshake IPAs contain between $1.5 \%$ and $2.0 \%$ lactose.

Apart from the use of lactose in beer to create a distinct sweetness, as mentioned before, the liquid runoff from the production of cheese (whey) has also been used in the production of beers [95]. A more contemporary use has been the use of the whey that results from the production of the renowned blue-veined cheese Stilton. In their "Blue Brew" beer [C10], the brewers mixed the whey with a freshly brewed wort directly into the fermenter, where the whey and the wort are co-fermented with a traditional brewers' yeast into a beer with a sweet ' $n$ sour creaminess due to the unfermented lactose from the whey. To date, there have been no reported cases of milk-related allergic reactions following the consumption of beer containing lactose or whey [27].

\subsection{Eggs as an Allergen in Beer}

The term eggs typically refers to hen eggs but does not exclude eggs from other birds. While in the various allergen regulations, there is typically no differentiation between eggs from different birds, cross-allergenicity is not always present [101]. Individuals with no hen egg allergies have been reported to have allergic reactions to quail, duck and geese eggs, and vice versa [101]. The allergic response to egg is due to proteins found in both the white and the yolk [102]. Among egg white proteins, ovalbumin was, for a long time, considered the standard egg allergen, but it was later shown that ovomucoid is the dominant allergen in eggs [103]. It is unheard of that eggs are used as an ingredient in the production of beer. However, the use of egg albumin (whites) in wine as a fining is at times employed to neutralise the effect of high levels of overly astringent tannins. This approach will hasten the maturation process in big, bold reds that would normally require extensive maturation periods.

In the 1980s, the Bass brewery brought out a strawberry-flavoured beer-like product that contained hydrolysed egg albumin as a foam enhancer [C11] [104,105]. The use of hydrolysed egg albumin was able to provide a polypeptide backbone to beers that had lacked sufficient nascent foam proteins or alcopops with high sugar adjuncts. However, beers produced with sufficient foam proteins did not greatly benefit from the addition of egg albumin [104]. The Bass brewery did not pursue the use of egg albumin any further due to allergic concerns [105] without further investigation.

\subsection{Celery as an Allergen in Beer}

Celery is part of the Apiaceae family, which includes carrots, parsnips, parsley, and celeriac. Both celery (Apium graveolens) and celeriac (Apium graveolens var. rapaceum) can cause allergic reactions in sensitive individuals (Table 1), which can result in an itchy mouth and throat by direct contact upon consumption [106]; in some individuals, celery can cause photosensitivity, resulting in blistered skin after only limited sun exposure [107]. As with almost all allergens, in severe cases, the consumption of celery can result in anaphylaxis. The major allergen associated with celery is "Api $\mathrm{g} 1$ ", which is a small protein with striking structural similarities to birch pollen and apple allergens [108].

Traditionally, celery has not been used as an ingredient in the production of beer. However, the rapid development of new beer variants conceived by the sprawling craft brewing industry has seen numerous beers with celery as a flavouring ingredient. In most, but not all, instances, the celery-containing beers are sours and goses, for instance, the mixed fermentation sour "Sellray Celery Ale" [C12] from the Pipeworks Brewing Company, while the American Black Shirt Brewing Company produced a "Celery Gose" [C13]. Furthermore, the New Zealand 8-Wired Brewery produces a "Celery Salt Hippy" 
[C14] within their "hippy range". Celery is not a declarable allergen in either New Zealand or the USA and is only declarable in the EU (and the broader EEA), UK, and Turkey (Table 2).

\subsection{Tree Nuts as Allergens in Beer}

Tree nuts are typically defined as any nut grown on a tree, which includes walnuts (Juglans regia), pecans (Carya illoinensis), almonds (Prunus amygdalus), cashews (Anacardium occidentale), brazil nuts (Bertholletia excelsa), pine nuts (Pinus pinea), hazelnuts (Corylus avellane), and macadamia (Macadamia integrifolia) nuts [109]. The majority of tree nut allergens are the numerous seed storage proteins found in all nuts [110], which have a high degree of homology among most tree nuts. This then means that there is a high level of cross-reactivity between most tree nuts, meaning that people with an allergenic response to one tree nut usually also have allergenic reactions to other tree nuts [109,110].

While many dark and brown beers are described as having a "nutty" flavour, that "nutty" sensory perception is typically due to the kilning and/or roasting of the malt at the end of the malting process. Brewing beer with nuts is uncommon; however, some examples are the hazelnut imperial stout "De Molen Hel \& Verdoemenis Hazelnoot" [C15], black walnuts in "Oil of Aphrodite" double stout [C16], almonds in the imperial stout "Biscotti Break" [C17], and pistachio nuts (Pistacia vera) in "Pistachio Cream Ale" [18]. The high lipid content in nuts will significantly reduce the foam volume of a poured beer; however, most of the beers brewed with nuts are high-alcohol beers, which will already affect foam volume.

\subsection{Peanuts (Groundnuts) as Allergens in Beer}

Despite the inclusion of the term "nut" in the name peanut, peanuts are not nuts [111]. Instead, peanuts (Arachis hypogaea) are legumes belonging to the same family as peas and beans. Peanuts develop and grow underground, while other nuts grow on trees, hence the term "tree nuts". Peanut allergens are very similar to tree nut allergens and, as such, contribute to a very large cross-reactivity with regards to allergenic responses, often causing life-threatening anaphylactic reactions [110,112].

Similar to beers that are brewed with tree nuts, peanuts have been included in darker beers as well. Typical examples include "Peanut Butter Milk stouts" [C19,C20] and "Peanut Butter and Jelly" brown ales [C21].

\subsection{Lupin as an Allergen in Beer}

Like peanuts, lupins belong to the legumes. Lupins (Lupinus albus) are a decorative flowering plant, which, unlike peanuts, produce edible beans in above-ground pods rather than underground. Individuals that are sensitive to peanuts are also likely to be allergic to lupins [113]. Because of the linked cross allergenicity between peanuts and lupins, lupins have been included in the list of compulsory labelling requirements of food allergens in the EU. The most common link between beer and lupins is that lupin beans are a common snack consumed with beer, especially in the Mediterranean region. The use of lupin as an ingredient in the production of beer is extremely uncommon. However, the Mean Sardine brewery in Portugal made a once-off "Lupini Bean Gose" [C22].

\subsection{Soy as an Allergen in Beer}

Soy is another legume but of Asian origin. Soy (Glycine max) is widely cultivated and used extensively as feed or food. Soy as food is readily used as a vegan alternative to animal-based proteins due to high levels of essential amino acids [114]. Soy contains about 15 proteins capable of eliciting an allergic reaction [115], with Gly-m-Bd-30K, Gly-m-Bd-28K and Gly-m-Bd-60K being the most allergenic among them.

Beer brewed with soy are rare; however, some beers containing soy-derived ingredients have made it onto the Japanese market. This appears to be mainly driven by a desire to produce beer-like products that do not meet the Japanese excise rules for beers. Locally, 
these beers are referred to as "third beers". An example is Kirin's "Nodogoshi Nama" [C23], which contains hops, sugar, soybean protein, and yeast extract. Similarly, Asahi's "New Life" [C24] also contain soybean peptides. On the other hand, the Tazawako brewery produced an "Akita Edamame" beer [C25] that contains edamame beans.

\subsection{Mustard as an Allergen in Beer}

Mustard is part of both the Brassica and Sinapis families (Brassica juncea and Sinapis alba, respectively). The major allergens associated with mustard seeds are "Sin a 1" and "Bra $\mathrm{j} 1$ " [116]. Both are small storage proteins found in mustard seeds only and are believed to provide sulphur and nitrogen to germinating seeds [117]. In sensitive humans, its immune-elicited response can cause asthma, allergic rhinitis and skin-related allergic reactions [116]. The use of mustard in the production of beer is uncommon. However, the Oskar Blues brewery produced a wheat-based ale flavoured with French yellow mustard [C26]. Along a similar vein, the Smisje brewery produced a full-malt ale with locally grown, crushed mustard seeds [C27].

\subsection{Sesame as an Allergen in Beer}

Sesame seeds are the seeds of the sesame plant (Sesamum indicum). The major allergens associated with sesame seeds are the " $2 S$ albumins" —Ses-i-1 and Ses-i-2 [118] — which are often targeted in the diagnosis of sesame-related allergies [119]. Sesame seeds have a mild, sweet, and nutty aroma and flavour and are used in tahini and hummus and often incorporated in crackers, breads, burger buns, salads and halvah. Sesame is an uncommon ingredient in beer but has the ability to provide a mild nutty sensory perception in darker and more acrid beers. The Serbian Kabinet brewery produced a chocolate beer in which roasted sesame seeds [C28] provided a rounded mouthfeel, while the Hungarian Zentis brewery produced a rich Christmas porter with dates, pine nuts and black sesame seeds [C29].

\subsection{Sulfur Dioxide as an Allergen in Beer}

Like lactose, sulfur dioxide $\left(\mathrm{SO}_{2}\right)$ is listed as an allergen; however, the impact from sulfites is typically an intolerance to sulphites acting as an irritant, causing airways becoming constricted. $\mathrm{SO}_{2}$ is specifically listed in the $2003 / 89 / \mathrm{EC} 1$ directive and is required to be identified when it is used as an ingredient at concentrations of more than $10 \mathrm{mg} / \mathrm{L}$. The same regulation regarding labelling exists in most countries. In some countries, specific regulations regarding allowable upper limits exist (Table 3). With varying regulations among countries, close scrutiny of an individual country's protocols is warranted when contemplating export.

Table 3. Country-specific regulations regarding $\mathrm{SO}_{2}$ in beer. Table modified from [26].

\begin{tabular}{ccc}
\hline Country/Region & Lower Limit Requiring Mention on Label (ppm) & Maximum Legal Limit (ppm) in Beer \\
\hline EU & 10 & 20 (50 with secondary fermentation in cask/barrel) \\
USA & 10 & 25 \\
Canada & 10 & 15 \\
Mexico & 10 & 15 \\
UK & 10 & 20 (50 with secondary fermentation in cask $/$ barrel $)$ \\
Russia & 10 & 20 (50 with secondary fermentation in cask/barrel) \\
Turkey & 10 & 20 \\
Australia & 10 & 25 \\
New Zealand & 10 & 25 \\
Singapore & 10 & unknown \\
Vietnam & 10 & 30 \\
Thailand & 10 & 50 \\
India & unknown & 50 \\
Brazil & unknown
\end{tabular}

In beer, $\mathrm{SO}_{2}$ is occasionally added to act as an antioxidant to scavenge oxidative compounds to delay the formation of carbonyl compounds (Figure 1), which could potentially 
lead to the formation of stale flavours [120]. The levels of $\mathrm{SO}_{2}$ typically added to beer are too low to impart an antimicrobial impact on the product, while other alcoholic beverages such as cider and wines often contain $\mathrm{SO}_{2}$ for antimicrobial purposes. These products require much higher additions compared to the use of $\mathrm{SO}_{2}$ as an antioxidative agent [26]. The principal reason why $\mathrm{SO}_{2}$ has, at best, a limited antimicrobial role in beers is that at the $\mathrm{pH}$ of typical beers, the $\mathrm{SO}_{2}$ is predominantly present in bisulfite form (Figure 2). The undissociated form $\left(\mathrm{SO}_{2} \mathrm{H}_{2} \mathrm{O}\right)$ is by far the most-effective bacteriostatic form, while the bisulfite form $\left(\mathrm{HSO}_{3}{ }^{-}\right)$has only a limited bacteriostatic effect and only when unbound [121,122]. At the $\mathrm{pH}$ of beer, the bisulfite ions are mostly bound to carbonyl compounds.<smiles>[R]C=CCCCCCC=O</smiles>

flavour active flavour inactive

Figure 1. $\mathrm{SO}_{2}$ reaction with carbonyls.

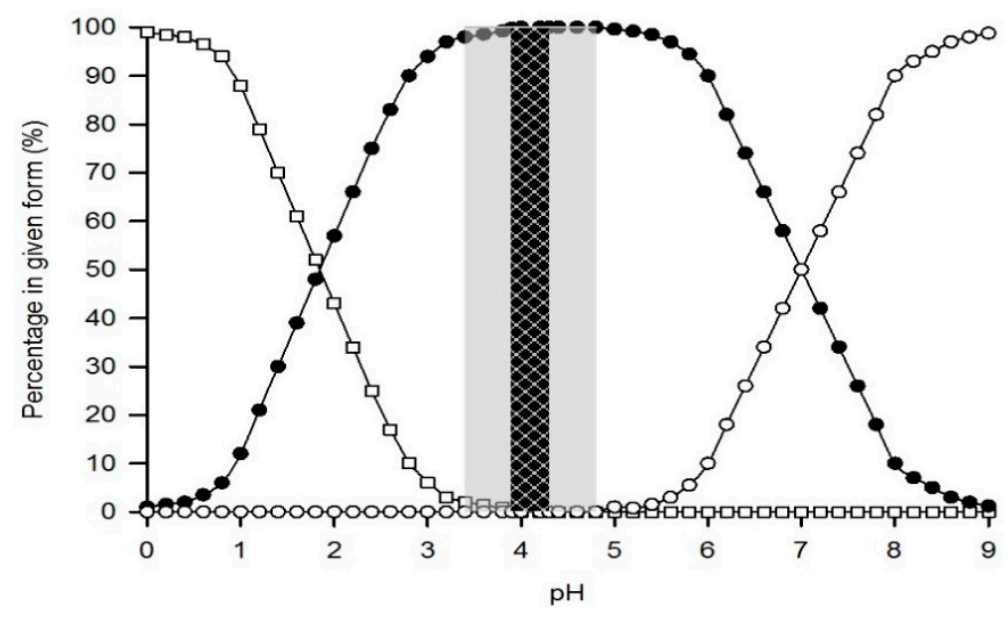

Figure 2. Effect of $\mathrm{pH}$ on the equilibria of $\mathrm{SO}_{2}$ species in aqueous solutions. $\square$ undissociated $\mathrm{SO}_{2} \cdot \mathrm{H}_{2} \mathrm{O}$; • bisulfite ion $\left(\mathrm{HSO}_{3}{ }^{-}\right)$; $\bigcirc$ sulphite ion $\left(\mathrm{SO}_{3}{ }^{2-}\right)$; shaded area represents the typical $\mathrm{pH}$ range of beers, with $50 \%$ of beers having a $\mathrm{pH}$ that falls within the darker hatched area. Figure adapted from [26].

\subsection{Miscellaneous Allergens in Beer}

Apart from the extensive list of compulsory labelling requirements for allergens, as obligated by the UK, there are numerous other compounds that can be associated with beers that also cause adverse, allergenic reactions. As mentioned before, with regards to a series of beer-allergen case studies, both yeast and hops have been reported to be the causative agent of beer-related anaphylaxes $[41,48,50,51]$. While not exclusively associated with beer, ethanol is known to cause diffuse erythema, which typically presents itself as facial flushing $[27,28]$.

Other less conventional, non-listed allergens are spices such as coriander (seeds or roots), which is a common flavouring agent in Belgian style witbeers such as "Hoegaarden Witbier" [C30] [42]. However, coriander has achieved a great following by brewers chasing a balance between citrus notes from hops and fruit with the additional spice depth awarded by coriander. Examples of these beers include Allagash "Hoppy Table Beer" [C31] and the Suarez family's "Settle Down Country Wit" [C32]. Other spices that are used as ingredients in beer are peppercorns, cumin, anise, fennel and fenugreek, which have all been shown to cause allergic reactions in those sensitive to them [123]. Examples of beers brewed with 
these spices include: "Pepper Johnson" [C33], "Taco hands" [C34], "Dragonwort Stout" [C35], "Marathos" [C36], and "Slow Down Brown" [C37].

Furthermore, a range of fruits that are incorporated in beer has been shown to cause allergenic reactions. These fruits include apple, prunes, cherries, mango, banana, pineapple and even tomatoes [124-126]. Probably the most well-known fruit beer is the Lambic beer [127], which enjoys the inclusion of cherries, raspberries and grapes [C38] [128]. Among the more exotic fruits that are incorporated in beers are bananas, such as in "Banana Bread Beer" [C39] and "Banoffee Pie Stout" [C40], and mango in milkshake IPAs [C09, C41, C42].

A more savoury fruit approach has been the inclusion of tomato. While a known allergen [126], tomatoes are not a common ingredient in beer. However, some examples do exist, such as "Sour Tomato Ale" [C43] and "Pizza IPA" [C44], containing dried tomatoes, basil, and oregano. In all these instances, a savoury and sour experience is highlighted by the inclusion of tomatoes, including a low-alcohol Mexican lager "Sol Clamato" [C45], where the inclusion of Clamato (a Mexican commercial drink made of reconstituted tomato juice concentrate and sugar, flavoured with spices and clam broth, and MSG) creates a powerful savoury sensory experience.

\section{Cross-Contamination Risks When Brewing with Allergens}

\subsection{Cross-Contamination with Unconventional Allergens}

While there are a number of allergens inherently associated with traditional beer, such as gluten and isinglass, as indicated above, there are also numerous allergens that are not part of the ordinary ingredients associated with beers. When brewing with potential allergens, it is imperative that brewers take great precautions to avoid any possible cross-over/contamination to ensure that the other beers are devoid of traces of unconventional allergens.

When it comes to allergens, many food companies incorporate rigorous cleaning regimes to ensure that allergen levels are within an acceptable range and to prevent the cross-contamination of allergens from one product to another [129]. Without this rigorous approach to allergen-orientated cleaning, failures can result in product recall and brand damage. The rigorous cleaning approach is often necessary because the validation of allergen removal during CIP is difficult to achieve [129,130]. The most common approach to achieving an allergen-specific CIP is through periodic off-line analysis of process swabs [131].

The vast majority of allergens are proteinaceous in nature, which means that a standard caustic clean (CIP) will most probably destroy and remove most allergens. Some of the allergens are associated with high-lipid ingredients such as tree nuts, peanuts and sesame. A standard caustic clean might not be sufficient in order to remove all traces of the ingredient-associated allergens. In those instances, an extended or repeated hot caustic treatment will be required. Stephan et al. [132] showed that peanut residues and celery residues were not sufficiently removed with a simple water-based prewash in their CIP application. However, subsequent caustic and acid washes did remove all traces of the allergens they studied.

The brewing process can deposit a large range of soils rich in proteins, sugars and waxy hops residues [133]. These soils can readily take up any range of unconventional allergens, which then become even more difficult to remove by standard brewing CIP methods. A sensible and practical approach to applying appropriate cleaning steps in a brewery where multiple batches of beer are being processed on a single day would be to process those beers with unconventional allergens at the end of the production day, when all other beers have already been processed. In that manner, the last beers to be processed of the day are also the last beers prior to the end-of-the-day CIP of the vessels, lines and other equipment. When multiple batches of beer with a range of unconventional allergens are to be processed on a single day, detailed process planning might be required in order to incorporate intermediate CIP processes to avoid allergen cross-contamination. 


\subsection{Cross-Contamination When Brewing Gluten-Free Beers}

Those breweries that brew both conventional gluten-containing beers and glutenfree beers (regardless of which gluten-free approach they employ) will encounter similar potential allergen cross-contamination conundrums, as mentioned above. In an unpublished study by Taylor and Vriesekoop [134] regarding breweries that brew gluten-free beers, the vast majority of gluten-free beer-producing breweries indicated that they also produced gluten-containing beer, with only $13 \%$ of breweries producing gluten-free beer choosing to exclusively produce gluten-free beer. This means that for the $87 \%$ of brewers that produce both conventional gluten-containing beer and gluten-free or gluten-reduced beers, steps have to be in place to avoid cross-contamination between their conventional and gluten-free beers. When asked what measures these breweries had in place to prevent such cross-contamination, most breweries replied they employed their standard CIP process. One brewer stated that they avoided cross-contamination through "thorough cleaning with caustic and acid, and if there are multiple transfers happening in one day, the gluten-reduced beer always goes first". Other brewers indicated that they avoided cross-contamination by brewing separate batches that "are made totally separately on different days, with full cleaning and sterilisation of all equipment between batches ... there is no chance of cross-contamination at any point". Some brewers mentioned the use of protein-degrading enzymes during their between-batches cleaning [134].

When brewing both conventional gluten-containing beers and gluten-free beers, it is recommended to process the gluten-free beers first following a complete CIP. This will avoid the chances of cross-contamination in the process lines and other equipment. A gluten-free specific CIP could be undertaken by applying proteolytic enzymes to remove gluten residues [135], with a range of potential enzymes available on the market $[26,70,136]$. These proteolytic enzymes could be applied to the initial CIP rinse and/or to the final, post-caustic rinse [137].

\section{Concluding Remarks}

While beer remains an inherently safe product to consume [127], the presence of hordiens (aka gluten) represent an intrinsic allergen associated with the vast majority of beers. Depending on some classical beer styles or processing steps, additional allergens such as milk/lactose or isinglass (fish) could make their way into beers. However, the boom in new beer varieties has seen most of the allergens that require compulsory listing on labels in the EU make their way into beers. The fact that compulsory allergen labelling is not uniformly applied in all countries can potentially cause confusion for producers and consumers alike. For producers, this means that exporting beers might require a change in labels, and for consumers, this means that they have to have an awareness that the familiarity with allergen labelling in their home country does not always translate to other countries.

In the vast majority of instances, allergens and allergic reactions are associated with the consumption of beer, with almost all ingredients associated with beer production having been identified as the cause of allergic reactions. However, the same allergens can also represent a continual presence in the workplace, where people working in the brewing and allied industries endure a persistent exposure to allergens without necessarily consuming beer.

In many instances, the less common beer-associated allergens are rare occurrences, even in the breweries that produce the beers that contain them. This means that crosscontamination of allergens needs to be considered in the production of a range of different beers within the same brewing environment. Production planning and thorough cleaning procedures following the processing of beer containing uncommon allergens are paramount to maintaining the allergen safety of all the other beers produced. The same also applies to the booming world of gluten-free beers. When considering the production of both gluten-free beers and gluten-containing beers, production planning and thorough cleaning procedures following the processing of beer containing gluten are paramount. 
Funding: This research received no external funding.

Institutional Review Board Statement: Not applicable.

Informed Consent Statement: Not applicable.

Data Availability Statement: Not applicable.

Conflicts of Interest: The authors declare no conflict of interest.

\section{Cerevisiography}

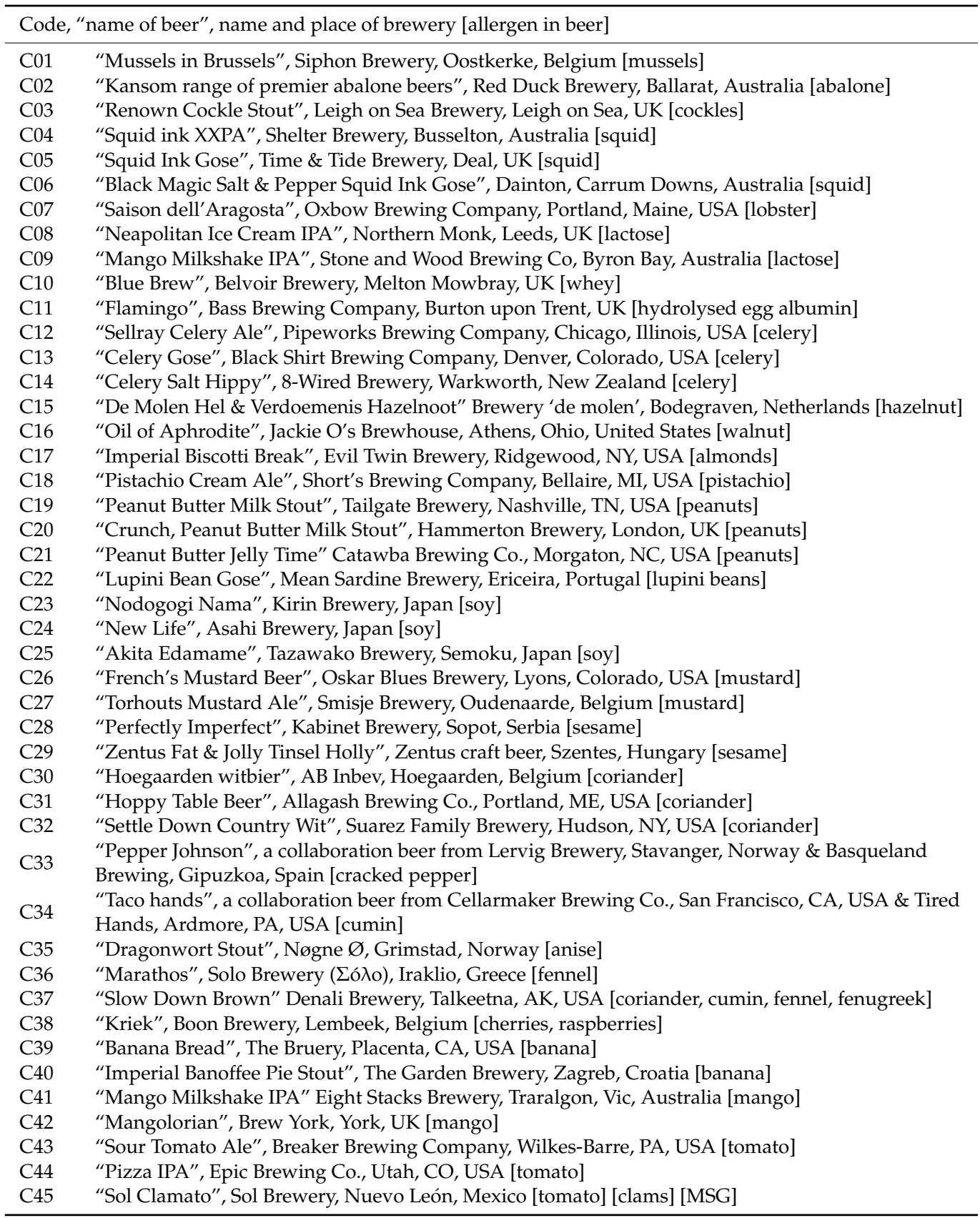




\section{References}

1. Sicherer, S.H.; Sampson, H.A. Food allergy: Epidemiology, pathogenesis, diagnosis, and treatment. J. Allergy Clin. Immunol. 2014, 133, 291-307. [CrossRef] [PubMed]

2. Versluis, A.; Knulst, A.C.; Kruizinga, A.G.; Michelsen, A.; Houben, G.F.; Baumert, J.L.; van Os-Medendorp, H. Frequency, severity and causes of unexpected allergic reactions to food: A systematic literature review. Clin. Exp. Allergy 2015, 45, 347-367. [CrossRef]

3. Jin, J. Treatments for Food Allergies. JAMA 2017, 318, 1945. [CrossRef] [PubMed]

4. Popping, B. Challenges in Detecting Food Allergens-Analytical Methods in the Legal Context. In The Science of Gluten-Free Foods and Beverages; Arendt, E.K., Bello, F.D., Eds.; AACC International Press: St. Paul, MN, USA, 2009; pp. 35-40.

5. Loh, W.; Tang, M.L. The epidemiology of food allergy in the global context. Int. J. Environ. Res. Public Health 2018, 15, 2043. [CrossRef]

6. Anon. Literature Searches and Reviews Related to The Prevalence of Food Allergy in Europe; EFSA Supporting Publications: Portsmouth, UK, 2013; Volume 10, EN-506.

7. Dostálek, P.; Dvorak, J.; Hulin, P. Allergens in beer. Kvas. Prum. 2010, 56, 105-108. [CrossRef]

8. Vriesekoop, F.; Wright, E.; Swinyard, S.; de Koning, W. Gluten-free products in the UK retail environment. Availability, pricing, consumer opinions in a longitudinal study. Int. J. Celiac Dis. 2020, 8, 95-103.

9. Public Law 108-282, an Act to Amend the Federal Food, Drug, and Cosmetic Act with Regard to New Animal Drugs, and for other Purposes. 2004. Available online: https:/ / www.govinfo.gov/app/details/PLAW-108publ282 (accessed on 7 December 2021).

10. CAA No. 322, Japanese Government Allergen Labelling. 2019. Available online: https://www.caa.go.jp/policies/policy/food_ labeling/food_sanitation/allergy/pdf/allergy_190925_0002.pdf (accessed on 7 December 2021).

11. EU Food Allergen Labelling. 2021. Available online: https://europa.eu/youreurope/business/product-requirements/foodlabelling/general-rules/index_en.htm\#shortcut-4 (accessed on 7 December 2021).

12. UK Food Allergen Labelling. 2021. Available online: https://www.food.gov.uk/business-guidance/allergen-guidance-for-foodbusinesses (accessed on 7 December 2021).

13. Turkey Food Allergen Labelling. 2021. Available online: https://www.tarimorman.gov.tr/Konu/2023/Toplu_Tuketim_ Yerlerinde_Alerjen_Bildirimi (accessed on 7 December 2021).

14. Australia and New Zealand Food Allergen Labelling. 2021. Available online: https://www.foodstandards.gov.au/consumer/ foodallergies / Pages/default.aspx (accessed on 7 December 2021).

15. Canada Food Allergen Labelling. 2021. Available online: https://www.canada.ca/en/health-canada/services/food-allergiesintolerances/avoiding-allergens-food/allergen-labelling.html (accessed on 7 December 2021).

16. Taiwan Food Allergen Labelling. 2021. Available online: https://www.mohw.gov.tw/dl-47353-14a49285-23d7-4c8c-ad7b-5cce7 09a6b09.html (accessed on 7 December 2021).

17. World Health Organisation Food Allergen Labelling. 2006. Available online: https://www.who.int/foodsafety/fs_management/ No_03_allergy_June06_en.pdf (accessed on 7 December 2021).

18. China Food Allergen Labelling. 2009. Available online: https://www.chinesestandard.net/PDF.aspx/GBT23779-2009 (accessed on 7 December 2021).

19. Mexico Food Allergen Labelling. NOM-051-SCFI/SSA1-2010. 2021. Available online: https://www.basham.com.mx/ministryof-economy-publishes-modifications-to-mexican-official-standard-nom-051-scfi-ssa1-2010-which-sets-forth-the-commercialand-sanitary-specifications-matters-of-labeling-for-pre-packaged-food-a/\#: \{\}:text=The\%20modifications $\% 20$ to $\% 20 \mathrm{NOM} \%$ 2D051, health\%20risks\%20if\%20consumed\%20excessively (accessed on 7 December 2021).

20. Russia Food Allergen Labelling. 2004. Available online: https://fsvps.gov.ru/fsvps-docs/ru/importExport/gonkong/files/ gonkong_tu_markdate.pdf (accessed on 7 December 2021).

21. Argentina Food Allergen Labelling. Acta No. 118. 2017. Available online: http://www.anmat.gov.ar/alimentos/directrices_ rotulado_alergenos.pdf (accessed on 7 December 2021).

22. Brazil Food Allergen Labelling. RDC No 26/15. 2017. Available online: https://www.gov.br/anvisa/pt-br/centraisdeconteudo/ publicacoes/alimentos / perguntas-e-respostas/rotulagem-de-alergenicos.pdf (accessed on 7 December 2021).

23. Chile Food Allergen Labelling. Decreto 88, Modifica Decreto 977 (1996). 2013. Available online: https://www.bcn.cl/leychile/ navegar?idNorma=1021822 (accessed on 7 December 2021).

24. International Regulatory Chart on Food Allergens. University of Nebraska-Lincoln. 2021. Available online: https:/ farrp.unl. edu/IRChart (accessed on 7 December 2021).

25. South Africa Food Allergen Labelling. No. 146. Staatskoerant Maart. 2010. Available online: https://www.sabio.org.za/ wp-content/uploads/2020/02/Foodstuffs-Cosmetics-and-Disenfectants-Act-Food-Labelling-Regs-R-146-of-1March-2010.pdf (accessed on 7 December 2021).

26. Vriesekoop, F. Product Integrity. In Handbook of Brewing; Stewart, G.G., Russell, I., Anstruther, A., Eds.; CRC Press: Boca Raton, FL, USA, 2017; pp. 653-678.

27. Drevets, C.C.; Seebohm, P.M. Dermatitis from alcohol. J. Allergy 1961, 32, 277-282. [CrossRef]

28. Igelman, S.J.; Na, C.; Simpson, E.L. Alcohol-induced facial flushing in a patient with atopic dermatitis treated with dupilumab. JAAD Case Rep. 2020, 6, 139-140. [CrossRef]

29. Koelemij, I.; Van Zuuren, E.J. Contact urticaria from beer. Clin. Exp. Dermatol. 2014, 39, 407-409. [CrossRef]

30. Gutgesell, C.; Fuchs, T. Contact urticaria from beer. Contact Derm. 1995, 33, 436-437. [CrossRef] 
31. Gupta, M.; Sharma, S.; Gupta, A. Beer induced angioedema-A case report. Our Dermatol. Online 2015, 6, 418-419. [CrossRef]

32. Curioni, A.; Santucci, B.; Cristaudo, A.; Canistraci, C.; Pietravalle, M.; Simonato, B.; Giannattasio, M. Urticaria from beer: An immediate hypersensitivity reaction due to a 10-kDa protein derived from barley. Clin. Exp. Allergy 1999, $29,407-413$. [CrossRef]

33. Pita, J.S.; Sousa, N.; Bartolome, B.; Loureiro, C.; Bom, A.T. Beer: An uncommon cause of anaphylaxis. BMJ Case Rep. 2019, 12, e227723. [CrossRef] [PubMed]

34. Figueredo, E.; Quirce, S.; Del Amo, A.; Cuesta, J.; Arrieta, I.; Lahoz, C.; Sastre, J. Beer-induced anaphylaxis: Identification of allergens. Allergy 1999, 54, 630-634. [CrossRef] [PubMed]

35. Fernández-Anaya, S.; Crespo, J.F.; Rodríguez, J.R.; Daroca, P.; Carmona, E.; Herraez, L.; López-Rubio, A. Beer anaphylaxis J. Allergy Clin. Immunol. 1999, 103, 959-960. [CrossRef]

36. Bonadonna, P.; Crivellaro, M.; Dama, A.; Senna, G.E.; Mistrello, G.; Passalacqua, G. Beer-induced anaphylaxis due to barley sensitization: Two case reports. J. Investig. Allergol. Clin. Immunol. 1999, 9, 268-270.

37. Asero, R.; Mistrello, G.; Roncarolo, D.; Amato, S.; van Ree, R. A case of allergy to beer showing cross-reactivity between lipid transfer proteins. Ann. Allergy Asthma Immunol. 2001, 87, 65-67. [CrossRef]

38. Nusem, D.; Panasoff, J. Beer anaphylaxis. Isr. Med. Assoc. J. 2009, 11, 380-381. [PubMed]

39. Herzinger, T.; Kick, G.; Ludolph-Hauser, D.; Przybilla, B. Anaphylaxis to wheat beer. Ann. Allergy Asthma Immunol. 2004, 92, 673-675. [CrossRef]

40. Quercia, O.; Zoccatelli, G.; Stefanini, G.F.; Mistrello, G.; Amato, S.; Bolla, M.; Emiliani, F.; Asero, R. Allergy to beer in LTP-sensitized patients: Beers are not all the same. Allergy 2012, 67, 1186-1189. [CrossRef] [PubMed]

41. Song, Z.; Chen, W.; Huang, X.; Zhou, X.; Luo, J.; Wang, H.; Darsow, U.; Becker, T.; Qian, F.; Hao, F.; et al. Sensitization to beer ingredients in Chinese individuals with beer allergy: A clinical study of 20 cases. Int. Arch. Allergy Immunol. 2014, 163, 135-141. [CrossRef]

42. Brussino, L.; Nicola, S.; Giorgis, V.; Rolla, G. Beer anaphylaxis due to coriander as hidden allergen. BMJ Case Rep. 2018, 2018, bcr-2018-225562. [CrossRef] [PubMed]

43. García-Casado, G.; Crespo, J.F.; Rodríguez, J.; Salcedo, G. Isolation and characterization of barley lipid transfer protein and protein $\mathrm{Z}$ as beer allergens. J. Allergy Clin. Immunol. 2001, 108, 647-649. [CrossRef] [PubMed]

44. Inoue, T.; Yagami, A.; Shimojo, N.; Hara, K.; Nakamura, M.; Matsunaga, K. Case of immediate hypersensitivity to beer. J. Dermatol. 2016, 43, 690-692. [CrossRef] [PubMed]

45. Chan-Yeung, M.; Dimich-Ward, H.; Enarson, D.A.; Kennedy, S.M. Five cross-sectional studies of grain elevator workers. Am. J. Epidemiol. 1992, 136, 1269-1279. [CrossRef] [PubMed]

46. Grant, I.W.; Blackadder, E.S.; Greenberg, M.; Blyth, W. Extrinsic allergic alveolitis in Scottish maltworkers. Br. Med. J. 1976, 1, 490-493. [CrossRef] [PubMed]

47. Miedinger, D.; Malo, J.L.; Cartier, A.; Labrecque, M. Malt can cause both occupational asthma and allergic alveolitis. Allergy 2009, 64, 1228-1229. [CrossRef] [PubMed]

48. Spiewak, R.; Gora, A.; Dutkiewicz, J. Work-related skin symptoms and type I allergy among eastern-Polish farmers growing hops and other crops. Ann. Agric. Environ. Med. 2001, 8, 51-56.

49. Reeb-Whitaker, C.K.; Bonauto, D.K. Respiratory disease associated with occupational inhalation to hop (Humulus lupulus) during harvest and processing. Ann. Allergy Asthma Immunol. 2014, 113, 534-538. [CrossRef] [PubMed]

50. Garcia, A. Occupational rhinoconjunctivitis due to hops exposure in a brewery worker. J. Allergy Clin. Immunol. 2004, 113, S62. [CrossRef]

51. Godnic-Cvar, J.; Zuskin, E.; Mustajbegovic, J.; Schachter, E.N.; Kanceljak, B.; Macan, J.; Ilic, Z.; Ebling, Z. Respiratory and immunological findings in brewery workers. Am. J. Ind. Med. 1999, 35, 68-75. [CrossRef]

52. Hadjivassiliou, M.; Sanders, D.S.; Aeschlimann, D. The Neuroimmunology of Gluten Intolerance. In Neuro-Immuno-Gastroenterology; Constantinescu, C., Arsenescu, R., Arsenescu, V., Eds.; Springer: Cham, Switzerland, 2016; pp. 263-285.

53. Cerf-Bensussan, N.; Meresse, B. Coeliac disease and gluten sensitivity: Epithelial stress enters the dance in coeliac disease Nat. Rev. Gastroenterol. Hepatol. 2015, 12, 491-492. [CrossRef]

54. Ludvigsson, J.F.; Leffler, D.A.; Bai, J.C.; Biagi, F.; Fasano, A.; Green, P.H.; Hadjivassiliou, M.; Kaukinen, K.; Kelly, C.P.; Leonard, J.N.; et al. The Oslo definitions for coeliac disease and related terms. Gut 2013, 62, 43-52. [CrossRef]

55. Hager, A.S.; Taylor, J.P.; Waters, D.M.; Arendt, E.K. Gluten free beer-A review. Trends Food Sci. Technol. 2014, 36, 44-54. [CrossRef]

56. Halmos, E.P.; Di Bella, C.A.; Webster, R.; Deng, M.; Tye-Din, J.A. Gluten in "gluten-free" food from food outlets in Melbourne: A cross-sectional study. Med. J. Aust. 2018, 209, 42-43. [CrossRef] [PubMed]

57. Dostálek, P.; Hochel, I.; Méndez, E.; Hernando, A.; Gabrovská, D. Immunochemical determination of gluten in malts and beers. Food Addit. Contam. 2006, 23, 1074-1078. [CrossRef]

58. Guerdrum, L.J.; Bamforth, C.W. Levels of gliadin in commercial beers. Food Chem. 2011, 129, 1783-1784. [CrossRef]

59. Koning, F.; Vader, W. Gluten peptides and celiac disease. Science 2003, 299, 513-515. [CrossRef]

60. Smulders, M.J.; van de Wiel, C.C.; van den Broeck, H.C.; van der Meer, I.M.; Israel-Hoevelaken, T.P.M.; Timmer, R.D.; van Dinter, B.J.; Braun, S.; Gilissen, L.J. Oats in healthy gluten-free and regular diets: A perspective. Food Res. Int. 2018, 110, 3-10. [CrossRef]

61. Kucek, L.K.; Veenstra, L.D.; Amnuaycheewa, P.; Sorrells, M.E. A grounded guide to gluten: How modern genotypes and processing impact wheat sensitivity. Compr. Rev. Food Sci. Food Saf. 2015, 14, 285-302. [CrossRef] [PubMed] 
62. Brauer, J.; Walker, C.; Booer, C. Of pseudocereals and roasted rice. The quest for gluten-free brewing materials. Brew. Distill. 2005, 1, 24-26.

63. de Meo, B.; Freeman, G.; Marconi, O.; Booer, C.; Perretti, G.; Fantozzi, P. Behaviour of malted cereals and pseudo-cereals for gluten-free beer production. J. Inst. Brew. 2011, 117, 541-546. [CrossRef]

64. Tanner, G.J.; Blundell, M.J.; Colgrave, M.L.; Howitt, C.A. Creation of the first ultra-low gluten barley (Hordeum vulgare L.) for coeliac and gluten-intolerant populations. Plant Biotechnol. J. 2016, 14, 1139-1150. [CrossRef] [PubMed]

65. Rybalka, O.; Katrii, V.; Polishchuk, S.; Morgun, B. Development of hull-less barley with ultra-low gluten content via target genes combination. I. Isolation of triple mutants and black grained genotypes. Agric. Sci. Pract. 2021, 8, 47-57. [CrossRef]

66. Park, J.W.; Kang, D.B.; Kim, C.W.; Ko, S.H.; Yum, H.Y.; Kim, K.E.; Hong, C.S.; Lee, K.Y. Identification and characterization of the major allergens of buckwheat. Allergy 2000, 55, 1035-1041. [CrossRef]

67. Stewart, G. Adjuncts. In Handbook of Brewing; Stewart, G.G., Russell, I., Anstruther, A., Eds.; CRC Press: Boca Raton, FL, USA, 2017; pp. 129-143.

68. Watson, H.G.; Vanderputten, D.; Van Landschoot, A.; Decloedt, A.I. Applicability of different brewhouse technologies and gluten-minimization treatments for the production of gluten-free (barley) malt beers: Pilot-to industrial-scale. J. Food Eng. 2019, 245, 33-42. [CrossRef]

69. Cela, N.; Condelli, N.; Caruso, M.C.; Perretti, G.; Di Cairano, M.; Tolve, R.; Galgano, F. Gluten-free brewing: Issues and perspectives. Fermentation 2020, 6, 53. [CrossRef]

70. van Zandijke, S. Gluten-reduced beers made with barley. New Brew. 2013, Nov. Dec., 79-84.

71. Walter, T.; Wieser, H.; Koehler, P. Degradation of gluten in wheat bran and bread drink by means of a proline-specific peptidase. J. Nutr. Food Sci. 2014, 4, 10-4172. [CrossRef]

72. van Landschoot, A. Gluten-free barley malt beers. Cerevisia 2011, 36, 93-97. [CrossRef]

73. Allred, L.K.; Lesko, K.; McKiernan, D.; Kupper, C.; Guandalini, S. The celiac patient antibody response to conventional and gluten-removed beer. J. AOAC Int. 2017, 100, 485-491. [CrossRef] [PubMed]

74. Real, A.; Comino, I.; Moreno, M.D.L.; Lopez-Casado, M.A.; Lorite, P.; Torres, M.I.; Cebolla, Á.; Sousa, C. Identification and in vitro reactivity of celiac immunoactive peptides in an apparent gluten-free beer. PLoS ONE 2014, 9, e100917. [CrossRef] [PubMed]

75. Boulton, C.; Quain, D. Brewing Yeast and Fermentation; Wiley-Blackwell: Oxford, UK, 2006; p. 660.

76. Hucker, B.; Vriesekoop, F.; Vriesekoop-Beswick, A.; Wakeling, L.; Vriesekoop-Beswick, H.; Hucker, A. Vitamins in brewing: Effects of post-fermentation treatments and exposure and maturation on the thiamine and riboflavin vitamer content of beer. J. Inst. Brew. 2016, 122, 278-288. [CrossRef]

77. Ryder, D. Processing Aids in Brewing. In Handbook of Brewing; Stewart, G.G., Russell, I., Anstruther, A., Eds.; CRC Press: Boca Raton, FL, USA, 2017; pp. 287-327.

78. Yildirim, H. Effects of fining agents on antioxidant capacity of red wines. J. Inst. Brew. 2011, 117, 55-60. [CrossRef]

79. Cosme, F.; Ricardo-da-Silva, J.M.; Laureano, O. Interactions between protein fining agents and proanthocyanidins in white wine. Food Chem. 2008, 106, 536-544. [CrossRef]

80. Hashim, P.; Ridzwan, M.M.; Bakar, J.; Hashim, M.D. Collagen in food and beverage industries. Int. Food Res. J. 2015, 22, 1-8.

81. André, F.; Cavagna, S.; André, C. Gelatine prepared from tuna skin: A risk factor for fish allergy or sensitization? Int. Arch. Allergy Immunol. 2003, 130, 17-24. [CrossRef] [PubMed]

82. Hansen, T.K.; Poulsen, L.K.; Skov, P.S.; Hefle, S.L.; Hlywka, J.J.; Taylor, S.L.; Bindslev-Jensen, U.; Bindslev-Jensen, C. A randomized, double-blinded, placebo-controlled oral challenge study to evaluate the allergenicity of commercial, food-grade fish gelatin. Food Chem. Toxicol. 2004, 42, 2037-2044. [CrossRef] [PubMed]

83. EFSA-EFSA Panel on Dietetic Products, Nutrition and Allergies (NDA). Opinion of the Scientific Panel on Dietetic Products, Nutrition and Allergies on a request from the Commission related to a notification from Brewers of Europe and BFBi on isinglass used as a clarifying agent in brewing pursuant to Article 6 paragraph 11 of Directive 2000/13/EC—For permanent exemption from labelling. EFSA J. 2007, 536, 1-10.

84. Walker, S.; Camarena, M.; Freeman, G. Alternatives to isinglass for beer clarification. J. Inst. Brew. 2007, 113, 347-354. [CrossRef]

85. Evans, J.G. The Exploitation of Molluscs. In The Domestication and Exploitation of Plants and Animals, 2nd ed.; Ucko, P.J., Dimbleby, G.W., Eds.; Routledge: New York, NY, USA, 2017; pp. 479-484.

86. Emoto, A.; Ishizaki, S.; Shiomi, K. Tropomyosins in gastropods and bivalves: Identification as major allergens and amino acid sequence features. Food Chem. 2009, 114, 634-641. [CrossRef]

87. Kamath, S.D.; Rahman, A.M.A.; Komoda, T.; Lopata, A.L. Impact of heat processing on the detection of the major shellfish allergen tropomyosin in crustaceans and molluscs using specific monoclonal antibodies. Food Chem. 2013, 141, 4031-4039. [CrossRef]

88. Brown, B.M. Oyster stout. J. Inst. Brew. 1939, 65, 77.

89. VanHook, A.M.; Patel, N.H. Crustaceans. Curr. Biol. 2008, 18, R547-R550. [CrossRef]

90. Fernandes, T.J.; Costa, J.; Oliveira, M.B.P.; Mafra, I. A new real-time PCR quantitative approach for the detection of shrimp crustaceans as potential allergens. J. Food Comp. Anal. 2018, 72, 7-14. [CrossRef]

91. Lin, S.Y.; Lee, C.H.; Huang, E.S.; Sheu, S.C.; Yu, H.S. Quantification of crustacean tropomyosin, a major food allergen, in eight species of Taiwanese shrimp based on immunoassay. Food Anal. Methods 2018, 11, 2607-2613. [CrossRef]

92. Cabral, J. Interview with Tim Adams, Oxbow Brewing Head Brewer. 2015. Available online: https://www.vice.com/en/article/ nz9kvd/we-spoke-to-the-man-who-brewed-a-dozen-lobsters-into-his-beer (accessed on 7 December 2021). 
93. Villa, C.; Costa, J.; Oliveira, M.B.P.; Mafra, I. Bovine milk allergens: A comprehensive review. Compr. Rev. Food Sci. Food Saf. 2018, 17, 137-164. [CrossRef] [PubMed]

94. Kokosinski, E. Improvement in the Manufacture of Beer. U.S. Patent 222,507, 2 October 1879.

95. Holsinger, V.H.; Posati, L.P.; DeVilbiss, E.D. Whey beverages: A review. J. Dairy Sci. 1974, 57, 849-859. [CrossRef]

96. Dietrich, K.R. Whey-containing malt wort as a raw material for the preparation of a malt-whey beer. Brauwissenschaft 1949, 2, 26.

97. Brunner, R.; Vogl, A. The production of beer with the use of whey. Gambrinus 1944, 5, 181.

98. Hesse, A. Molkegetränke (whey beverages). Z. Lebensm. Unters. Forsch. 1948, 88, 499-506. [CrossRef]

99. Pavsler, A.; Buiatti, S. Non-Lager Beer. In Beer in Health and Disease Prevention; Preedy, V.R., Ed.; Elsevier: Amsterdam, The Netherlands; Academic Press: Cambridge, MA, USA, 2009; pp. 17-31.

100. Harding, L. Whey. Int. J. Dairy Technol. 1963, 16, 53-61. [CrossRef]

101. Liu, Y.; Qiu, N.; Gao, D.; Ma, M. Comparative proteomic analysis of chicken, duck, and quail egg yolks. Int. J. Food Prop. 2018, 21, 1311-1321. [CrossRef]

102. Anet, J.; Back, J.F.; Baker, R.S.; Barnett, D.; Burley, R.W.; Howden, M.E.H. Allergens in the white and yolk of hen's egg. Int. Arch Allergy Immunol. 1985, 77, 364-371. [CrossRef] [PubMed]

103. Mine, Y.; Rupa, P. Immunological and biochemical properties of egg allergens. Worlds Poult. Sci. J. 2004, 60, 321-330. [CrossRef]

104. Bamforth, C.W.; Cope, R. Egg albumen as a source of foam polypeptide in beer. J. Am. Soc. Brew. Chem. 1987, 45, 27-32. [CrossRef]

105. Bamforth, C.W. Enzymes, Egg White, and Eccentrics: Memories from 37 Years of Research in the Brewing Industry. J. Am. Soc. Brew. Chem. 2016, 74, 1-15. [CrossRef]

106. Dölle, S.; Welter, S.; Ruppel, E.; Lehmann, K.; Schwarz, D.; Jensen-Jarolim, E.; Zieglmayer, P.; Franken, P.; Worm, M. Clinical reactivity of celery cultivars in allergic patients: Role of Api g 1. Clin. Exp. Allergy 2018, 48, 424-432. [CrossRef] [PubMed]

107. Birmingham, D.J.; Key, M.M.; Tubich, G.E.; Perone, V.B. Phototoxic bullae among celery harvesters. Arch. Dermatol. 1961, 83, 73-87. [CrossRef]

108. Poncet, P.; Sénéchal, H.; Charpin, D. Update on pollen-food allergy syndrome. Expert Rev. Clin. Immunol. 2020, 16, 561-578. [CrossRef] [PubMed]

109. Smeekens, J.M.; Bagley, K.; Kulis, M. Tree nut allergies: Allergen homology, cross-reactivity, and implications for therapy. Clin. Exp. Allergy 2018, 48, 762-772. [CrossRef] [PubMed]

110. de Leon, M.P.; Glaspole, I.N.; Drew, A.C.; Rolland, J.M.; O’Hehir, R.E.; Suphioglu, C. Immunological analysis of allergenic cross-reactivity between peanut and tree nuts. Clin. Exp. Allergy 2003, 33, 1273-1280. [CrossRef] [PubMed]

111. Hussain, Z. Food Allergy. J. Immunol. Infect. Dis. 2017, 4, 202. [CrossRef]

112. Bublin, M.; Breiteneder, H. Cross-reactivity of peanut allergens. Curr. Allergy Asthma Rep. 2014, 14, 426. [CrossRef]

113. Sirtori, E.; Resta, D.; Arnoldi, A.; Savelkoul, H.F.; Wichers, H.J. Cross-reactivity between peanut and lupin proteins. Food Chem. 2011, 126, 902-910. [CrossRef]

114. Kumar, V.; Rani, A.; Hussain, L. Essential amino acids profile of differentially processed soy products and their efficiency in meeting daily requirement. Nutr. Food Sci. 2016, 46, 237-245. [CrossRef]

115. Ogawa, T.; Samoto, M.; Takahashi, K. Soybean allergens and hypoallergenic soybean products. J. Nutr. Sci. Vitaminol. 2000, 46, 271-279. [CrossRef]

116. Sharma, A.; Verma, A.K.; Gupta, R.K.; Dwivedi, P.D. A comprehensive review on mustard-induced allergy and implications for human health. Clin. Rev. Allergy Immunol. 2019, 57, 39-54. [CrossRef]

117. Oñaderra, M.; Monsalve, R.I.; Mancheño, J.M.; Villalba, M.; Del Pozo, A.M.; Gavilanes, J.G.; Rodriguez, R. Food mustard allergen interaction with phospholipid vesicles. Eur. J. Biochem. 1994, 225, 609-615. [CrossRef] [PubMed]

118. Adatia, A.; Clarke, A.E.; Yanishevsky, Y.; Ben-Shoshan, M. Sesame allergy: Current perspectives. J. Asthma Allergy 2017, 10, 41-151. [CrossRef]

119. Ehlers, A.M.; Rossnagel, M.; Brix, B.; Blankestijn, M.A.; Le, T.M.; Suer, W.; Otten, H.G.; Knulst, A.C. Sesame oleosins are minor allergens. Clin. Transl. Allergy 2019, 9, 32. [CrossRef] [PubMed]

120. Lachenmeier, D.W.; Nerlich, U. Evaluation of sulphite in beer and spirits after the new allergen labelling rules. Brew. Sci. 2006, 59, 114-117.

121. Ilett, D.R. Aspects of the analysis, role, and fate of sulphur dioxide in beer-A review. Tech. Q. Master Brew. Assoc. Am. 1995, 32, 213-221.

122. Guido, L.F. Sulfites in beer: Reviewing regulation, analysis and role. Sci. Agric. 2016, 73, 189-197. [CrossRef]

123. Chen, J.L.; Bahna, S.L. Spice allergy. Ann. Allergy Asthma Immunol. 2011, 107, 191-199. [CrossRef]

124. Scheurer, S.; Pastorello, E.A.; Wangorsch, A.; Kästner, M.; Haustein, D.; Vieths, S. Recombinant allergens Pru av 1 and Pru av 4 and a newly identified lipid transfer protein in the in vitro diagnosis of cherry allergy. J. Allergy Clin. Immunol. 2001, 107, 724-731. [CrossRef]

125. Hassan, A.K.; Venkatesh, Y.P. An overview of fruit allergy and the causative allergens. Eur. Ann. Allergy Clin. Immunol. 2015, 47, 180-187. [PubMed]

126. Kurze, E.; Lo Scalzo, R.; Campanelli, G.; Schwab, W. Effect of tomato variety, cultivation, climate and processing on Sola 14 , an allergen from Solanum lycopersicum. PLoS ONE 2018, 13, e0197971. [CrossRef] [PubMed]

127. Vriesekoop, F.; Krahl, M.; Hucker, B.; Menz, G. 125th Anniversary Review: Bacteria in brewing: The good, the bad and the ugly. J. Inst. Brew. 2012, 118, 335-345. [CrossRef] 
128. Baigts-Allende, D.K.; Pérez-Alva, A.; Ramírez-Rodrigues, M.A.; Palacios, A.; Ramírez-Rodrigues, M.M. A comparative study of polyphenolic and amino acid profiles of commercial fruit beers. J. Food Comp. Anal. 2021, 100, 103921. [CrossRef]

129. Trinh, L.; Willey, A.R.; Martin, P.J.; Ashley, J.; Tothill, I.E.; Rodgers, T.L. Rate-based approach to cleaning-in-place. Ind. Eng. Chem. Res. 2017, 56, 6695-6702. [CrossRef]

130. Fryer, P.J.; Robbins, P.T.; Asteriadou, K. Current knowledge in hygienic design: Can we minimize fouling and speed cleaning? Procedia Food Sci. 2011, 1, 1753-1760. [CrossRef]

131. Stephan, O.; Weisz, N.; Vieths, S.; Weiser, T.; Rabe, B.; Vatterott, W. Protein quantification, sandwich ELISA, and real-time PCR used to monitor industrial cleaning procedures for contamination with peanut and celery allergens. J. AOAC Int. 2004, 87, 1448-1457. [CrossRef] [PubMed]

132. Martin, E.; Montague, G.; Robbins, P. A quality by design approach to process plant cleaning. Chem. Eng. Res. Des. 2013, 91, 1095-1105. [CrossRef]

133. Barnes, Z. Cleaning in Place (CIP). In Handbook of Brewing; Stewart, G.G., Russell, I., Anstruther, A., Eds.; CRC Press: Boca Raton, FL, USA, 2017; pp. 415-431.

134. Taylor, S.; Vriesekoop, F. Assessing the Factors behind the Increase in Gluten Free Beer. Honours Dissertation, Harper Adams University, Newport, UK, 2017.

135. Fuciños, C.; Estévez, N.; Míguez, M.; Fajardo, P.; Chapela, M.J.; Gondar, D.; Rúa, M.L. Effectiveness of proteolytic enzymes to remove gluten residues and feasibility of incorporating them into cleaning products for industrial purposes. Food Res. Int. 2019, 120, 167-177. [CrossRef]

136. Banerjee, S.; Ranganathan, V.; Arora, A.; Patti, A.F. 2021. Green approach towards hydrolysing wheat gluten using waste ingredients from pineapple processing industries. Int. J. Food Sci. Technol. 2021, 56, 1724-1733. [CrossRef]

137. Sarver, R.W.; Almy, D.J.; Bergeron, E.R.; Strong, B.F.; Steiner, B.A.; Donofrio, R.; Lupo, A.J.; Gray, R.L.; Sperry, A.K. Overview of Portable Assays for the Detection of Mycotoxins, Allergens, and Sanitation Monitoring. J. AOAC Int. 2021, 104, 39-48. [CrossRef] 